\title{
Evaluation of gunshot wounds in the emergency department
}

\author{
Mehmet Ali Karaca, M.D., ${ }^{1}$ Nil Deniz Kartal, M.D., ${ }^{1}$ Bülent Erbil, M.D., ${ }^{1}$ Elif Öztürk, M.D., ${ }^{1}$ \\ Mehmet Mahir Kunt, M.D., ${ }^{1}$ Tevfik Tolga Şahin, M.D., ${ }^{2}$ Mehmet Mahir Özmen, M.D. ${ }^{2}$
}

${ }^{1}$ Department of Emergency Medicine, Hacettepe University, Faculty of Medicine, Ankara

${ }^{2}$ Department of General Surgery, Hacettepe University Faculty of Medicine, Ankara

\begin{abstract}
BACKGROUND: This study aimed to evaluate injury patterns of patients admitted to the emergency department with gunshot wounds, results of imaging studies, treatment modalities, outcomes, mortality ratios, and complications.

METHODS: A retrospective descriptive study was carried out including a total number of one hundred and forty-two patients admitted to Hacettepe University Emergency Department with gunshot injuries between January I, I999 and December 3I, 20I3. The Glasgow Coma Scale (GCS), Revised Trauma Score (RTS), Injury Severity Score (ISS), and theTrauma and Injury Severity Score (TRISS) probability of survival for penetrating trauma were calculated for all patients.
\end{abstract}

RESULTS: Among the one hundred and forty-two patients in the study, one hundred and twenty-eight (90.1\%) were male. Mean age was 36 years. On admission, the average GCS score was 13, mean RTS was 6.64, median ISS was 5 and median TRISS probability for survival was $99.4 \%$ for penetrating trauma. Fluid was detected in three (13\%) patients in FAST, whereas intra-abdominal solid organ injury and bowel injury were detected in I I (58\%) patients in abdominal CT. The pneumothorax, hemothorax and lung injuries were detected in $10(40 \%)$ patients, whereas hemothorax was detected only in one patient with thoracic injury by chest X-ray. Twenty four (16.9\%) patients died; eighteen patients $(75 \%)$ had isolated severe intracranial injuries, two (8.3\%) had thoracic injuries with head and neck injuries, and four (16.7\%) patients had intra-abdominal organ injuries (one with concomitant head injury). Ten patients were brought to the ED in cardiopulmonary arrest. In dead patients, GCS, RTS and TRISS were significantly lower, and ISS were significantly higher than in surviving patients. Twenty three $(95.8 \%)$ patients were in critical injury level (ISS $25-75$, actually ISS $>50$ ) in the exitus group.

CONCLUSION: Mortality rates in gunshot wound patients with cranial injuries are very high. Spontaneous return is not seen in patients brought to the ED in arrest state. Bullets can cause internal organ injuries which can be greater than expected. In thoracoabdominal gunshot wound injuries, conventional X-ray and bedside FAST can be ineffective in detecting the whole extent of intrathoracic and intra-abdominal injuries. Thus, thoracic and abdominal CT should be planned early for hemodynamically stable patients in order to eliminate causes of fatality and make a timely and correct diagnosis. ISS, RTS and GCS are useful in predicting prognosis and mortality. Especially in patients with ISS scores $>50$, the mortality rate can be as high as $96 \%$.

Key words: Emergency department; GCS; gunshot injury; ISS; RTS; trauma; TRISS.

\section{INTRODUCTION}

Firearms can be obtained very easily in our country as well as in the world; therefore, the injury and mortality rates due to firearms are steadily increasing. Nationwide, firearms were

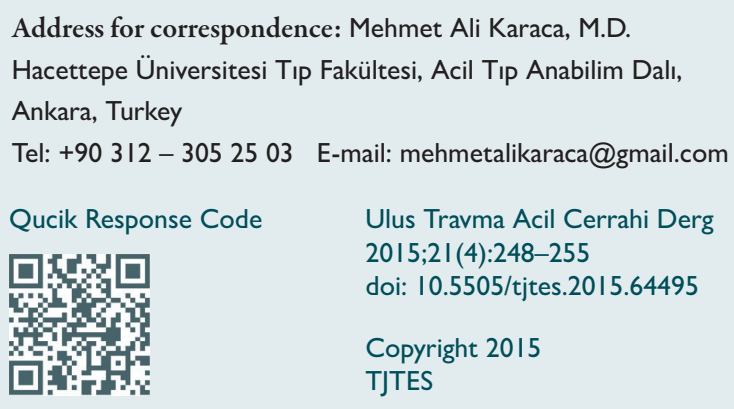

the third-leading cause of injury-related deaths following poisoning and motor vehicle accidents in 2010. In 2010, approximately 31.000 deaths occurred in the USA due to gunshot wounds. This is the equivalent of more than 85 deaths per day in the emergency department (ED). Furthermore, 73.505 Americans were treated in the ERs for non-fatal gunshot wounds in 2010. ${ }^{[1]}$

Injuries are related to the energy and speed of the bullet. Bullets spin in through their route, and therefore, cause much more severe injuries than expected. Initial physical findings may not correlate to actual injuries, and the physician may be faced with a more severe case than anticipated. Many of these patients could be spending the golden hours of trauma in admission. Early evaluation and intervention in patients with gunshot injuries is, therefore, of most importance. 
Table I. Characteristic of patients

\begin{tabular}{lll}
\hline & Mean (Min-Max) & \\
\hline Age & $36(18-77)$ & \\
Systolic blood pressure $(\mathrm{mmHg})$ & $110(0-239)$ & $(<90 \mathrm{mmHg}$ in 25) \\
Diastolic blood pressure $(\mathrm{mmHg})$ & $68(0-136)$ & $(<60 \mathrm{mmHg}$ in 23) \\
Heart rate (beats/min) & $87(0-156)$ & $(>120 \mathrm{~b} / \mathrm{min}$ in I4) \\
Respiratory rate $($ resp/min) & $18(0-77)$ & $(>30 \mathrm{resp} / \mathrm{min}$ in 5) \\
Glasgow Coma Scale & $13(3-15)$ & $(<15$ in 30) \\
Revised Trauma Score & $6.64(0-7.84)$ & $($ Median 7.74) \\
Injury Severity Score & $16.34(1-75)$ & (Median 5.0) \\
TRISS & $80.69 \%(0.1-99.4)$ & (Median 99.1\%) \\
Length of stay (day) & $4(0.2-60)$ & \\
Mortality ratio & $16.9 \%$ & \\
\hline
\end{tabular}

TRISS: Trauma and Injury Severity Score probability of survival rate for penetrating trauma.

This study aimed to evaluate injury patterns of patients admitted to the emergency department with gunshot wounds, results of imaging studies, treatment modalities, outcomes, mortality ratios, and complications.

\section{MATERIALS AND METHODS}

A retrospective descriptive study was carried out including a total number of one hundred and forty-two patients admitted to Hacettepe University Emergency Department with gunshot injuries between January I, 1999 and December 3I, 2013. The Glasgow Coma Scale (GCS), Revised Trauma Score (RTS), Injury Severity Score (ISS), and the Trauma and Injury Severity Score (TRISS) probability of survival for blunt trauma and penetrating trauma were calculated for all patients. The extent of injury was graded according to the ISS as: mild $(I-8)$, moderate (9-I4), severe (I5-24) and critical $(\geq 25)$. [2] In the present study, the evaluated parameters included mechanism of injury, results and types of diagnostic imaging, modality of treatment, consulted departments, hospitalization ratio, length of stay and complication rate and type.
Statistical analysis was performed using the Statistical Package for Social Sciences (SPSS) version 2I for Windows, and $\mathrm{p}<0.05$ was considered significant. Mean values were used and independent $t$ test was applied in normally distributed variants, median values were used and Mann-Whitney $U$ test was applied in non-normally distributed variants. The relations of categorical variants were evaluated with an $\mathrm{X}^{2}$ test.

\section{RESULTS}

Demographic characteristics of the patients are summarized in Table I. Among the one hundred and forty-two patients in the study, one hundred and twenty-eigh $(90.1 \%)$ were male. Mean age was 36 (range, 18-77) years.

As for the location of the injuries, the majority of injuries were detected in the lower extremities $(n=68,47.9 \%)$, the head and neck $(n=44,31 \%)$ and upper extremities $(n=4 I$, 28.9\%) (Table 2). On admission, hypotension was detected in twenty-five (18\%), tachycardia in fourteen (10\%) and tachypnea in five (4\%) patients. On admission, GCS, RTS, ISS and

Table 2. Injury area and scores

\begin{tabular}{|c|c|c|c|c|c|c|c|}
\hline Injury site & $\mathbf{n}$ & $\%$ & $\begin{array}{c}\text { GCS } \\
\text { Mean (min-max) }\end{array}$ & $\begin{array}{c}\text { RTS } \\
\text { Mean (min-max) }\end{array}$ & $\begin{array}{c}\text { ISS } \\
\text { Mean (min-max) }\end{array}$ & $\begin{array}{c}\text { TRISS (\%) } \\
\text { Mean (min-max) }\end{array}$ & $\begin{array}{c}\text { Mortality } \\
(n=24)\end{array}$ \\
\hline Lower extremity & 68 & 48 & $14.5(12-15)$ & $7.6(7.11-7.84)$ & $7(I-I I)$ & 98.5 (96.5-99.4) & \\
\hline Head and neck & 44 & 31 & $9(3-15)$ & $4.7(0-7.84)$ & $34(1-75)$ & $50.8(0.1-88.4)$ & 18 \\
\hline Upper extremity & 41 & 29 & $14(13-15)$ & $7.3(6.47-7.84)$ & $9(1-14)$ & 96.4 (88-99.4) & \\
\hline Thorax & 36 & 25 & $13(3-15)$ & $6.6(0-7.84)$ & $20(3-75)$ & $77.8(I-97.2)$ & $2^{*}$ \\
\hline Abdominal & 16 & II & $13(3-15)$ & $6.5(0-7.84)$ & $19(2-75)$ & $79.7(0.1-91.3)$ & $4^{\dagger}$ \\
\hline
\end{tabular}

GCS: Glasgow Coma Scale; RTS: Revised Trauma Score; ISS: Injury Severity Score; TRISS: Trauma and Injury Severity Score probability of survival rate for penetrating trauma ( $* 2$ patients with concomitant head and neck injury, $\dagger$ one patient had concomitant head trauma). 
Table 3. Injury area and imaging studies

\begin{tabular}{|c|c|c|c|c|c|c|c|}
\hline Injury site & $\mathbf{n}$ & $\%$ & $\begin{array}{c}X-R a y \\
(n=64)\end{array}$ & $\begin{array}{c}\text { FAST } \\
(n=23)\end{array}$ & $\begin{array}{c}\text { Cranial CT } \\
(n=23)\end{array}$ & $\begin{array}{l}\text { Thorax CT } \\
(n=25)\end{array}$ & $\begin{array}{c}\text { Abdominal CT } \\
(n=19)\end{array}$ \\
\hline Lower extremity & 68 & 48 & $\begin{array}{l}\text { Bone fractures } \\
\pm \text { bullet }(n=22)\end{array}$ & & & & \\
\hline Head-Neck & 44 & 31 & & & $\begin{array}{l}\text { Intracranial injury } \\
\qquad(n=20)\end{array}$ & & \\
\hline Upper extremity & 41 & 29 & $\begin{array}{l}\text { Bone fractures } \\
\pm \text { bullet }(n=16)\end{array}$ & & & & \\
\hline Thorax & 36 & 25 & Hemothorax $(n=I)$ & & & $\begin{array}{l}\text { Pneumo-hemothorax } \\
\qquad(n=10)\end{array}$ & \\
\hline Abdominal & 16 & II & & Fluid $(n=3)$ & & & $\begin{array}{l}\text { Solid organ and bowel } \\
\text { injury }(n=I I)\end{array}$ \\
\hline
\end{tabular}

FAST: Focused assessment with sonography for trauma.

TRISS were calculated and the average GCS score was 13. The Glasgow Coma Scale score was lower than 15 in thirty (21\%) patients. Mean RTS was 6.64 (0-7.84). Mean ISS was 16.34, median ISS was $5(1-75)$. Mean TRISS probability of survival was $80.6 \%(0.1-9.4 \%)$, and median TRISS probability for survival was $99.4 \%$ for penetrating trauma. The results of the scoring systems are summarized in Table 2.

The results of the diagnostic imaging are summarized in Table 3. The diagnostic imaging modalities and their results were evaluated. Conventional plain $\mathrm{X}$-ray graphics were the most commonly utilized imaging modality. It was helpful when performed for injuries in the extremities and to detect the projectile object in the torso and extremities of the individual. $X$-ray was performed in sixty-four patients, bullet fragments and bone fractures in extremities were detected in thirtyeight (59\%).

Focused assessment with sonography for trauma (FAST) was performed in twenty-three patients, and fluid was detected in three (13\%) patients. Abdominal computed tomography (CT) was performed in nineteen patients and intra-abdominal solid organ injury and bowel injury were detected in eleven (58\%) patients. There was superiority of abdominal CT in detecting of intra-abdominal injury in abdominal trauma patients $(p<0.001)$. Thorax CT was performed in twenty-five patients and pneumothorax, hemothorax and lung injuries were detected in ten (40\%) patients, whereas hemothorax was detected only in one patient with thoracic injury by chest X-ray. The sensitivity of thorax CT was much higher in detecting intra-thoracic organ injury in gunshot wounds than $X$-ray $(p<0.00 I)$. Cranial CT was performed in twentythree patients, and major intracranial injuries were detected in twenty (87\%) of these patients on cranial CT. This shows the fact that cranial CT is usually ordered in very specific conditions, and therefore, the specificity and sensitivity in detecting cranial lesions in the setting of gunshot injury is very high.

Table 4. Consultations and treatment

\begin{tabular}{|c|c|c|c|c|c|}
\hline \multirow[t]{2}{*}{ Department } & \multirow[t]{2}{*}{$\mathbf{n}$} & \multirow[t]{2}{*}{$\%$} & \multicolumn{3}{|c|}{ Procedures $(n=142)$} \\
\hline & & & Surgery & Wound care & Dressing \\
\hline Orthopedic & 72 & 51 & 23 & 33 & 2 \\
\hline Thoracic-Cardiovascular Surgery & 52 & 37 & 12 & 16 & \\
\hline Brain Surgery & 27 & 19 & 15 & 2 & \\
\hline Plastic \& Reconstructive Surgery & 26 & 18 & 8 & 7 & 6 \\
\hline General Surgery & 21 & 15 & 7 & 4 & \\
\hline Ear-Nose-Throat & 5 & 3.5 & 3 & 1 & \\
\hline Ophthalmology & 2 & 1.4 & & 1 & \\
\hline Urology & 2 & 1.4 & 2 & & \\
\hline Total & & & $70(49 \%)$ & $64(45 \%)$ & $8(6 \%)$ \\
\hline
\end{tabular}


Table 5. Injury area and scores

\begin{tabular}{lcccccc}
\hline Outcome & $\mathbf{n}$ & $\%$ & $\begin{array}{c}\text { GCS } \\
\text { Mean (min-max) }\end{array}$ & $\begin{array}{c}\text { ISS } \\
\text { Mean (min-max) }\end{array}$ & $\begin{array}{c}\text { RTS } \\
\text { Mean (min-max) }\end{array}$ & $\begin{array}{c}\text { TRISS (\%) } \\
\text { Mean (min-max) }\end{array}$ \\
\hline ED-discharge & 55 & 38.7 & 15 & $4.4(I-26)$ & $7.82(7.55-7.84)$ & $99.2(97.2-99.4)$ \\
Ward-discharge & 49 & 34.5 & $14.4(5-15)$ & $11.6(2-50)$ & $7.41(1.87-7.84)$ & $91.5(8.9-99.3)$ \\
ICU-discharge & 4 & 2.8 & $12.7(6-15)$ & $15.7(2-29)$ & $7.58(7.11-7.84)$ & $97.3(93.3-99.2)$ \\
Treatment refusal & 7 & 4.9 & 15 & $5.7(1-16)$ & $7.63(6.38-7.84)$ & $98.9(97.5-99.4)$ \\
Refer to another hospital & 3 & 2.1 & 15 & $6.3(4-9)$ & 7.84 & $99.2(99.1-99.3)$ \\
Exitus & 24 & 16.9 & $3.5(3-8)$ & $57.7(16-75)$ & $1.77(0-3.87)$ & $5.8(0.1-44)$ \\
Total & 142 & 100 & & & & \\
\hline
\end{tabular}

GCS: Glasgow Coma Scale; RTS: Revised Trauma Score; ISS: Injury Severity Score; TRISS: Trauma and Injury Severity Score probability of survival rate for penetrating trauma. ED: Emergency Department; ICU: Intensive Care Unit.

The consulted departments and the results are summarized in Table 4. The most frequent consultations were to orthopedics (5l\%), thoracic-cardiovascular surgery (37\%), neurosurgery (19\%), plastic surgery (18\%) and general surgery (14.8\%) respectively. Seventy patients (49\%) underwent surgical treatment, local wound care was performed in sixtyfour (45\%) and dressing was performed only in eight (6\%) patients. The most frequent surgical procedures were performed by the orthopedics $(n=23,16 \%)$ and neurosurgery departments $(n=15,15 \%)$.

The outcomes of the patients are summarized in Table 5. Fifty-five $(38.4 \%)$ patients were treated and discharged from the emergency department (ED), and forty-nine (34.5\%) patients were hospitalized and discharged from various in-patient wards, four (2.8\%) of the patients were hospitalized in the intensive care unit (ICU) and twenty-four (I6.9\%) patients died. The average length of stay in the hospital was 4 days. The average lengths of stay in the ED, in-patient wards and the ICU were 10 hours, 8 days and 16 days, respectively.

Complications developed in ten $(7 \%)$ patients, which are summarized in Table 6. The most frequent complication was central and peripheral nervous system injury.

Twenty four (16.9\%) patients died; fifteen of these $(62.5 \%)$ died within 24 hours. Eighteen of the patients that died (75\%) had isolated severe intracranial injuries, two (8.3\%) had thoracic injuries with head and neck injuries, and four (16.7\%) patients had intra-abdominal organ injuries (one with concomitant head injury). Ten patients were brought to the ED in cardiopulmonary arrest. Twelve patients $(50 \%)$ died in the ED (seven of these were brought in arrest), eight (33.3\%) patients died in the Neurosurgery ICU (one of these was brought in arrest) and four patients (16.7\%) died in the peri/ postoperative period in the general surgery department (two of these were brought in arrest). One patient who died in the Neurosurgery ICU was accepted as an organ donor two days following hospitalization.
Mortality ratios of patients according to injured part of body were as follows: head and neck trauma: $41 \%$, thorax trauma: $5.5 \%$, abdominal trauma: $25 \%$. In consideration of radiological findings, mortality ratios in case of critical injury were as follows: the mortality in intracranial injury was $90 \%$, in thoracic injury it was $20 \%$ and in intra-abdominal injury it was $36 \%$. There was significant increase in mortality ratios in patients with intracranial injury $(p<0.00 \mathrm{I})$. The mortality ratio of $p a-$ tients that were brought to the ED in arrest state was $100 \%$. Arrest state in admission to ED could be an independent risk factor for mortality in gunshot wounds.

On admission physiologic and anatomic trauma scores were calculated for each injury area of body. GCS, RTS, TRISS probability for survival were significantly lower and ISS was higher in head and neck trauma patients than other groups (GSC: 9, RTS: 4.7 , TRISS: $50.8 \%$, and ISS: 34$)(p=0.00 \mathrm{I})$. In contrast, RTS, and TRISS were significantly higher and ISS scores significantly lower in extremity trauma patients $(p=0.0 \mathrm{I})$ (Table 2).

Physiologic and anatomic scores were compared according to the outcome in dead and surviving patients. In dead patients, GCS, RTS and TRISS were significantly lower and ISS were significantly higher than in surviving patients $(p=0.00 \mathrm{I})$ (Table 5).

When the patients' outcome was compared to ISS grades;

Table 6. Complications

\begin{tabular}{lc}
\hline Complications & $\mathbf{n}$ \\
\hline Quadriplegia/paraplegia & 4 \\
Brachial plexus and peripheral nerve palsy & 2 \\
Pneumonia & 2 \\
Wound infection & 1 \\
Amputation & 1 \\
Total & 10 \\
\hline
\end{tabular}


one patient (4.2\%) was in severe injury levels (ISS I5-24) and twenty-three (95.8\%) patients were in critical injury level (ISS 25-75, actually ISS $>50$ ) in the exitus group. In addition, $75 \%$ of patients treated and discharged from the ICU had in severe and critical injury grades, whereas $89.1 \%$ of the patients treated and discharged from ED had mild ISS grades (I-9). These differences between the groups were statistically significant $(p=0.001)$ (Table 7).

\section{DISCUSSION}

While gunshot deaths were previously prevalent in the military arena, they have also become more widespread among the general public since the 1980s due to the proliferation of firearms acquired by civilians. Thus, the number of patients with gunshot wounds admitted to civil hospital emergency departments is steadily on the rise. ${ }^{[3]}$

Two different types of firearms are produced with low and high bullet speeds. Bullets with high speed have high levels of energy and cause greater tissue damage than others because of cavitation formation. The bullet trajectory is curved due to gravity, and as the bullet strikes an object it slows, and its energy is transferred to the object. Thus, most bullets can be found in bone fragments. The density of tissue affects the efficiency of energy transmission. Similarly, the strength and elasticity of an object determine the degree of damage. Solid organs are dense and have low resilience. Fluid filled hollow organs transmit energy and cause increased damage. However, air filled organs absorb energy, and therefore, cause less damage. Air in lungs absorbs energy; the parenchyma is compressed and rebounds, thus pneumothorax or hemothorax can occur. Bone resists displacement until it shatters. The cavitational energy trapped inside the skull causes serious and lethal bleeding. ${ }^{[4-6]}$

Gunshot wounds are most prevalent among males aged 3040. Karagoz et al. have stated the percentage as 3.75. ${ }^{[7]}$ Molina et al. have stated that the mean age in patients who attempted suicide with firearms is 46.7 , whereas the mean age of gunshot victims is 34.3 , the male to female ration being $5: I$. The same ratio is 10:I according to Balci et al., while Köksal et al. claim that males comprise $88.9 \%$ of all victims, and that the mean age 34.5. In our study, similarly to the data on mean age in the literature, we found the mean age to be 36 and the male to female ratio, corresponding to Balci and Köksal, to be 9:I. ${ }^{[8-10]}$

Anatomical and physiological patient scores (GCS, RTS and ISS) were found to be similar to other studies while ISS scores were lower. The lower ISS results in our study are thought to be due to the prevalence of injuries in extremities. ${ }^{[I]}$

The distribution of injuries on the body diagram shows a similar tendency to prevalence as in the study by Sheffy et al. who stated lower extremity injuries to be the most predominant $(42 \%)$, followed by head and neck injuries (39\%) and thoracic injuries $(23.5 \%){ }^{[1]}$ Our study similarly showed the most common injuries to be in the lower extremities (48\%), followed by head and neck injuries (31\%) and injuries to the thorax. Due to the prevalence of injuries to the extremities, the most frequent consultations in our study were to the orthopedics department, followed by the cardiothoracic surgery and neurosurgery departments.

In most cases of penetrating trauma, surgical treatment is necessary. Rates for this treatment vary according to the location and severity of the injury. In their study on gunshot and explosion injuries, Peleg et al. have stated surgical treatment to be necessary in $58 \%$ of gunshot wound cases. ${ }^{[12]}$ Martins et al. have found the rate of surgical treatment in penetrating cranial injuries to be $58.9 \%$. ${ }^{[13]}$ The rate of surgical treatment for injuries to the extremities and femur fractures in civilian patients is $46 \%{ }^{[14]}$ In the penetrating abdominal injury guide, the rate of early laparotomy in thoracoabdominal injuries is $23 \%$, while the rate of laparotomy in general is $48 \%$. The rate of local wound exploration is $47 \%{ }^{[15]}$ Similarly to the rates in the literature, we found in our study that $49 \%$ of patients received surgical treatment. The highest rate of surgical treat-

Table 7. Outcome vs ISS grades

\begin{tabular}{|c|c|c|c|c|c|c|c|c|c|c|}
\hline \multirow[t]{2}{*}{ Outcome } & \multicolumn{2}{|c|}{ Mild (I-8) } & \multicolumn{2}{|c|}{ Moderate (9-14) } & \multicolumn{2}{|c|}{ Severe $(15-24)$} & \multicolumn{2}{|c|}{ Critical ( $\geq 25)$} & \multicolumn{2}{|c|}{ Total } \\
\hline & $\mathbf{n}$ & $\%$ & $\mathbf{n}$ & $\%$ & $\mathbf{n}$ & $\%$ & $\mathbf{n}$ & $\%$ & $\mathbf{n}$ & $\%$ \\
\hline ED-discharge & 49 & 89.1 & 4 & 7.3 & I & 1.8 & I & 1.8 & 55 & 100 \\
\hline Ward-discharge & 26 & 53.1 & 8 & 16.3 & 6 & 12.2 & 9 & 18.4 & 49 & 100 \\
\hline ICU-discharge & I & 25 & 0 & 0 & 2 & 50 & $\mathrm{I}$ & 25 & 4 & 100 \\
\hline Treatment refusal & 6 & 85.7 & 0 & 0 & 1 & 14.3 & 0 & 0 & 7 & 100 \\
\hline Refer to another hospital & 2 & 66.7 & I & 33.3 & 0 & 0 & 0 & 0 & 3 & 100 \\
\hline Exitus & 0 & 0 & 0 & 0 & 1 & 4.2 & 23 & 95.8 & 24 & 100 \\
\hline Total & 84 & 59.2 & 13 & 9.2 & 11 & 7.7 & 34 & 23.9 & 142 & 100 \\
\hline
\end{tabular}

ED: Emergency Department; ICU: Intensive Care Unit. 
ment $(55 \%)$ was found in the case of patients with head and neck injuries, followed by those with abdominal injuries (33\%) and injuries to the extremities (32\%). Local wound care was performed on $45 \%$ of the patients.

Diagnostic imaging (X-rays, USG and CT) is commonly performed in gunshot wounds to spot pathologies. X-ray imaging is very helpful in injuries to the extremities, to detect pathologies in the bone tissue, bullets, and bullet fragments. In thoracoabdominal injuries, X-ray imaging is very valuable in detecting hemothorax, pneumothorax and injuries to the diaphragm, as well as spotting bullet fragments. ${ }^{[16,17]}$ In our study, X-ray proved valuable in detecting pathologies in the bone tissue in $60 \%$ of extremity injury cases.

FAST and CT are steadily becoming more important in the diagnosis of thoracic and abdominal injuries. While bullet exit wounds are easily identifiable during physical examination, the same examination cannot detect the path of the bullet and the damage caused within the tissues. $\left.{ }^{[1]}\right]$ Intra-abdominal free fluid and increase of fluid in the pericardial cavity can be spotted with bedside FAST imaging. In hemodynamically unstable patients, early detection of intra-abdominal injuries facilitates early diagnosis and treatment. Diaphragm injuries and vascular injuries are common in gunshot wounds due to the ballistic effect of the bullet, but hard to detect with X-ray; they can, however, be spotted with thorax CT which is also useful in detecting lung injuries, pneumothorax, hemothorax, cardiac injuries and hemopericardium (with 100\% sensitivity).

In gunshot wounds to the abdomen, abdominal CT is useful for providing information on the bullet's path through the tissue. While bedside FAST imaging is useful for detecting intraabdominal injuries, it is ineffective in spotting retroperitoneal and intestinal injuries. Abdominal CT, useful in this case, also makes non-surgical observation of gunshot wound patients possible. ${ }^{[15]}$ In our study, X-ray only detected hemothorax in one of the patients with thoracic injuries while damages to the lungs and hemo-pneumothorax were found in ten of the 25 patients in the same group (40\%) with thoracic CT. Similarly, FAST performed on twenty-three patients with gunshot wounds to the abdomen detected free fluid in only three of them (13\%) while abdominal CT spotted damage including intra-abdominal solid organ and bowel injury in eleven of the 19 patients (58\%) on whom it was performed. This shows that in hemodinamically stable gunshot wound patients, thoracoabdominal CT should be performed for timely and correct diagnosis. In the case of patients with head and neck injuries, CT is regarded as the most valuable imaging method for identifying pathologies and arriving at prognoses. ${ }^{[1]}$ In our study, cranial CT performed on twenty-three patients in the group with head and neck injuries revealed intracranial injuries in 20 of them (87\%).

The severity of gunshot wound cases admitted to the ED and the distribution and number of affected organs determine hospitalization rates. Köksal et al. have found the hospitalization rate in gunshot wound patients to be $75 \%$ and the rate of patients treated in the ED and discharged to be $5 \%$. Mean length of the hospital stay was found to be 9 days. ${ }^{[10]}$ Peleg et al. have found the rate of ICU stays for gunshot wound patients to be $23 \%$, with longer stays in the case of multiple wounds. ${ }^{[12]}$ In our study, ICU stay rate was found to be $2.8 \%$ and the mean length of ICU stay to be four days. The comparatively short hospital stay durations are thought to be due to the low rate of patients hospitalized in the ICU.

Mortality is high in gunshot wound cases and is influenced by the location of the injury and the number of organs affected. Studies have found the general mortality rate in gunshot wound cases to be between 12 and $16 \%$. While mortality is $17 \%$ in the case of isolated injury to the chest and abdomen, it is $80 \%$ in the case of abdominal injuries with concomitant brain and lung injury. Gunshot injury deaths generally occur within the first day. ${ }^{[10-12]}$ The general mortality rate in our study was \%16.9 ( $n=24)$. Twelve of the patients who died (50\%) did so in the ED; seven of these had been brought to the ED in the arrest state. In patients with isolated intracranial injuries, the mortality rate was $41 \%$. One patient with cranial injury became an organ donor.

Our study found return of spontaneous breathing and circulation to be very low in the case of patients with intracranial injuries brought to the ED in the arrest state. All of these patients died. Since patients with isolated head trauma are likely candidates for organ donation, cardiopulmonary resuscitation should be performed on these patients.

There are several studies about the efficacy of scoring systems for severity of injuries, prognosis and predicting mortality in gunshot wound patients. GCS, RTS, ISS and TRISS probability for survival are the scoring systems most commonly used in these cases. Low GCS (especially $<5$ ), low RTS and ISS higher than 16 (especially 16-75) have been found to be linked to high mortality rates. ${ }^{[10-13,18-21]}$

Some recent studies indicate that in numerous patient groups, evaluating ISS scores of 25-75 showing critical injury in two parts of ISS 25-48 and 50-75 would be more useful. ${ }^{[22]}$ Similarly to the finding in literature, our studye found the GCS and RTS scores and TRISS levels of exitus patients to be significantly low and their ISS levels to be significantly high (GKS: 3.5, ISS: 57.7, TRISS survival for penetrating trauma: 5.8). As many as $95.8 \%$ of the exitus patients had critical injuries according to ISS. The GCS and RTS scores calculated by taking injury locations into account were significantly lower in head and neck injuries than in other injuries. These findings show that low GCS $(<5)$ and high ISS $(>50)$ scores are useful and serviceable in predicting prognosis and mortality in gunshot wound patients. Complications in gunshot wound cases depend on the location and severity of the injury. Injuries affecting the neurological system and causing long-term neurological damage are 
especially important. ${ }^{[23]}$ In our study, the rate of complication development was found to be $7 \%$ with the most common complications being those affecting the central and peripheral nervous system.

\section{Conclusion}

Mortality rates in gunshot wound patients with cranial injuries are very high. Spontaneous return is not seen in patients brought to the ED in arrest state, but patients with isolated intracranial injuries should be considered potential organ donors and resuscitated.

Bullets have high velocity and energy, which can cause internal organ injuries greater than expected. In thoracoabdominal gunshot wound injuries, conventional $X$-ray and bedside FAST can be ineffective in detecting the whole extent of intrathoracic and intra-abdominal injuries. Thus, thoracic and abdominal CT should be planned early for hemodynamically stable patients in order to eliminate causes of fatality and make a timely and correct diagnosis. ISS, RTS and GCS are useful in predicting prognosis and mortality. Especially in patients with ISS scores $>50$, the mortality rate can be as high as $96 \%$.

\section{Conflict of interest: None declared.}

\section{REFERENCES}

1. Statistics on Gun Deaths \& Injuries (Posted on November 16, 2012). Available at http://smartgunlaws.org/gun-deaths-and-injuries-statistics/(Accessed 12.03.2015).

2. Baker SP, O'Neill B, Haddon W Jr, Long WB. The injury severity score: a method for describing patients with multiple injuries and evaluating emergency care. J Trauma 1974;14:187-96. CrossRef

3. Necmioğlu NS, Subaşı M. Ateşli Silah yaralanması ile oluşan uzun kemiklerin tedavisi. TOTBİD Dergisi 2003;2:3-4:118-25.

4. Yılmaz A. Ateşli silahlarla oluşan yaralanmalar. TTB Dergisi 2004;50:167-78.

5. Bartlett CS, Helfet DL, Hausman MR, Strauss E. Ballistics and gunshot wounds: effects on musculoskeletal tissues. J Am Acad Orthop Surg 2000;8:21-36.

6. Eriş S, Orak M, Al B, Güloğlu C, Aldemir M. Factors Affectıng Mortality In Patients With Gunshot Injuries. Marmara Medical Journal 2009;22;181-91.

7. Karagoz YM, Karagöz SD, Atılgan M, Demircan C. An Analysis of 133 Fiream Deaths. Adli Tip Bülteni. 1996;1:122-6.
8. Molina DK, DiMaio VJ, Cave R. Handgun wounds: a review of range and location as pertaining to manner of death. Am J Forensic Med Pathol 2013;34:342-7. CrossRef

9. Balci Y, Canogullari G, Ulupinar E. Characterization of the gunshot suicides. J Forensic Leg Med 2007;14:203-8. CrossRef

10. Köksal O, Ozdemir F, Bulut M, Aydin S, Almacioğlu ML, Ozgüç H. Comparison of trauma scoring systems for predicting mortality in firearm injuries. Ulus Travma Acil Cerrahi Derg 2009;15:559-64.

11. Sheffy N, Mintz Y, Rivkind AI, Shapira SC. Terror-related injuries: a comparison of gunshot wounds versus secondary-fragments-induced injuries from explosives. J Am Coll Surg 2006;203:297-303. CrossRef

12. Peleg K, Aharonson-Daniel L, Stein M, Michaelson M, Kluger Y, Simon D, et al. Gunshot and explosion injuries: characteristics, outcomes, and implications for care of terror-related injuries in Israel. Ann Surg 2004;239:311-8. CrossRef

13. Martins RS, Siqueira MG, Santos MT, Zanon-Collange N, Moraes OJ. Prognostic factors and treatment of penetrating gunshot wounds to the head. Surg Neurol 2003;60:98-104. CrossRef

14. Vaidya R, Sethi A, Oliphant BW, Gibson V, Sethi S, Meehan R. Civilian gunshot injuries of the humerus. Orthopedics 2014;37:307-12. CrossRef

15. Biffl WL, Moore EE. Management guidelines for penetrating abdominal trauma. Curr Opin Crit Care 2010;16:609-17. CrossRef

16. Öztürk H, Dokucu AI, Otcu S, Onen A. The prognostic importance of trauma scoring systems for morbidity in children with penetrating abdominal wounds: 17 years of experience. J Pediatr Surg 2002;37:93-8.

17. Reginelli A, Russo A, Maresca D, Martiniello C, Cappabianca S, Brunese L. Imaging assessment of gunshot wounds. Semin Ultrasound CT MR 2015;36:57-67. CrossRef

18. Finley CJ, Hemenway D, Clifton J, Brown DR, Simons RK, Hameed SM. The demographics of significant firearm injury in Canadian trauma centres and the associated predictors of inhospital mortality. Can J Surg 2008;51:197-203.

19. Smith JE, Kehoe A, Harrisson SE, Russell R, Midwinter M. Outcome of penetrating intracranial injuries in a military setting. Injury 2014;45:874-8.

20. de Souza RB, Todeschini AB, Veiga JC, Saade N, de Aguiar GB. Traumatic brain injury by a firearm projectile: a 16 years experience of the neurosurgery service of Santa Casa de São Paulo. Rev Col Bras Cir 2013;40:300-4.

21. Eryılmaz M, Tezel O, Taş H, Arzıman I, Oğünç GI, Kaldırım U, et al. The relationship between Injury Severity Scores and transfusion requirements of 108 consecutive cases injured with high kinetic energy weapons: a tertiary center end-mode mortality analysis. [Article in Turkish] Ulus Travma Acil Cerrahi Derg 2014;20:39-44. CrossRef

22. Rozenfeld M, Radomislensky I, Freedman L, Givon A, Novikov I, Peleg K. ISS groups: are we speaking the same language? Inj Prev 2014;20:330-5.

23. Topuz AK, Eroğlu A, Atabey C, Cetinkal A. Surgical treatment outcomes in peripheral nerve lesions due to gunshot injuries: assessment of 28 cases. [Article in Turkish] Ulus Travma Acil Cerrahi Derg 2013;19:235-40. 


\title{
ORİJINAL ÇALIŞMA - ÖZET
}

\section{Acil serviste ateşli silah yaralanmalarının analizi \\ Dr. Mehmet Ali Karaca, ${ }^{1}$ Dr. Nil Deniz Kartal, ${ }^{1}$ Dr. Bülent Erbil,, ${ }^{1}$ Dr. Elif Öztürk, Dr. Mehmet Mahir Kunt, ${ }^{1}$ Dr. Tevfik Tolga Şahin, ${ }^{2}$ Dr. Mehmet Mahir Özmen ${ }^{2}$}

\author{
${ }^{1}$ Hacettepe Üniversitesi Tıp Fakültesi, Acil Tıp Anabilim Dalı, Ankara \\ ${ }^{2}$ Hacettepe Üniversitesi Tıp Fakültesi, Genel Cerrahi Anabilim Dalı, Ankara
}

AMAÇ: Bu çalışmada, acil servise ateşli silah yaralanması nedeniyle başvuran hastaların yaralanma özellikleri, görüntüleme yöntemlerinin sonuçları, tedavi türleri, sonlanım, ölüm ve komplikasyon oranları araştııılı.

GEREÇ VE YÖNTEM: Bu geriye dönük tanımlayıcı çalışmaya I Ocak 1999 ile 3 I Aralık 2013 tarihleri arasında Hacettepe Üniversitesi Erişkin Acil Servisi'ne ateşli silah yaranması nedeniyle getirilen 142 hasta alındı. Tüm hastalar için Glaskow Koma Skalası (GKS), Revize Travma Skoru (RTS), Yaralanma Ciddiyet Skoru (ISS) ve penetran yaralanmalarda Travma ve Yaralanma Ciddiyet Skoru ve Sağkalım Olasılığı (TRISS) oranları hesaplandı. BULGULAR: Çalışmaya alınan I42 hastanın I28'i (\%90.I) erkekti. Ortalama yaş 36 olarak hesaplandı. Başvuru anında ortalama GKS skoru I3, ortalama RTS 6.64, ortanca ISS 5 ve ortanca TRISS penetran travma için sağ kalım olasılığı \%99.4 hesaplandı. FAST ile hastaların üçünde (\%।3) karın içi serbest sıvı saptanırken abdomen bilgisayarlı tomografi (BT) ile hastaların I I'inde (\%58) solid organ ve bağırsak yaralanması saptandı. Direkt akciğer grafisi ile bir hastada hemotoraks saptanırken, toraks BT ile 10 (\%40) hastada pnömotoraks, hemotoraks ve akciğer yaralanması tespit edildi. Çalışmada 24 hasta hayatını kaybetti; 18 (\%75) hastada izole intrakraniyal yaralanma, iki (\%8.3) hastada baş boyun yaralanmanın eşlik ettiği toraks yaralanması, dört (\%।6.7) hastada karın içi organ yaralanması (bir hastada kraniyal yaralanma eşlik ediyordu) bulunuyordu. Acil servise 10 hasta kardiyopulmoner arrest olarak getirildi. Hayatını kaybeden hastalarda GKS, RTS ve TRISS yaşayan hastalara göre anlamlı derecede düşük, ISS ise anlamlı derecede yüksek saptandı. Hayatını kaybeden hastaların 23'ü (\%95.8) ISS'ye göre kritik yaralanma düzeyine (ISS 25-75, aralığında ve ISS >50) sahipti.

TARTIŞMA: Ateşli silahlara bağlı kraniyal yaralanmalarda mortalite düzeyleri çok yüksektir. Acil servise arrest olarak getirilen hastalarda spontan geri dönüş görülmemektedir. Kurşuna bağı iç organ hasarı tahmin edilenden daha fazla olmaktadır. Toraks ve abdomendeki ateşli silah yaralanmalarında direkt grafiler ve FAST tanıda yetersiz olabilmektedir. Bu nedenle bu hastalarda ölümcül olan yaralanmaların erken dönemde tespit edilmesi için toraks ve abdomen BT istemi erken dönemde planlanmalıdır. Yaralanma Ciddiyet Skoru, RTS ve GKS prognoz ve mortaliteyi öngörmede yaralıdır. Özellikle ISS >50 olgularda mortalite oranı \%96'ya kadar yükselmektedir.

Anahtar sözcükler: Acil servis; GKS; ateşli silah yaralanması; ISS; RTS; travma; TRISS.

Ulus Travma Acil Cerrahi Derg 2015;2I (4):248-255 doi: 10.5505/tjtes.20I5.64495 